\title{
Combined Electrochemical and X-ray Tomography Study of the High Temperature Evolution of Nickel - Yttria Stabilized Zirconia Solid Oxide Fuel Cell Anodes
}

David Kennouche ${ }^{1}$, Yu-chen Karen Chen-Wiegart ${ }^{2}$, Casey Riscoe ${ }^{1}$, Jun Wang ${ }^{2}$, Scott A. Barnett $^{1{ }^{*}}$

${ }^{1}$ Department of Materials Science and Engineering, Northwestern University, Evanston, Illinois, USA

${ }^{2}$ Photon Science Directorate, Brookhaven National Laboratory, Upton, New York, USA

* Corresponding author. Email: s-barnett@northwestern.edu, phone: +1-847-491-2447, fax: +1-847-4917820

Keywords: solid oxide fuel cell; anode; Temperature evolution; model; three phase boundaries; polarization resistance

\section{Abstract}

Accelerated ageing of Ni-Yttria Stabilized Zirconia (YSZ) anode functional layers (AFLs) in solid oxide fuel cells (SOFCs) is carried out at $1000-1200^{\circ} \mathrm{C}$, the resulting morphological changes are investigated using transmission X-ray microscopy (TXM), and properties are characterized using electrochemical impedance spectroscopy (EIS). Prior to ageing, the as prepared NiO-YSZ AFLs are reduced to Ni-YSZ and then aged at $1100{ }^{\circ} \mathrm{C}$ for $100 \mathrm{~h}$ in order to eliminate early-stage morphological changes. Measured particle size and three phase boundary (TPB) density changes with ageing time and temperature are fit reasonably well using a power-law coarsening model. This model is also used in conjunction with an electrochemical model to predict changes in the anode charge-transfer polarization resistance. The models are used to make predictions of the structural and electrochemical performance 
evolution of these Ni-YSZ anodes, for cells operated long-term at normal $\left(700-850^{\circ} \mathrm{C}\right)$ operating temperatures. Additional experiments to verify the model predictions are suggested.

\section{Introduction}

Coarsening and sintering of the Ni phase in Ni-YSZ anodes has long been considered a key issue for solid oxide fuel cell (SOFC) durability. A typical SOFC operating temperature of $1073 \mathrm{~K}$ is $\sim 62 \%$ of the melting point of $\mathrm{Ni}$, high enough to expect considerable coarsening and sintering, although the YSZ phase helps to constrain Ni coarsening. There are several mechanisms by which fuel cell Ni-YSZ anodes may degrade during the operation of a stack. However, the coarsening and sintering of a porous electrode structure is of interest because it places an ultimate limit on electrode durability.

A key problem with characterizing electrode stability is the long lifetime expected for commercial devices, e.g., > 40,000 h. Tests over this time frame involve a long delay in achieving the desired results, and relatively few data points can be obtained. Thus, most studies have employed an alternative strategy - accelerated testing - typically employing temperatures higher than normally used in SOFC operation to accelerate ageing processes. The relatively short testing times allow a substantial number of measurements. However, useful predictions require extrapolation of the results to longer times and lower temperatures if the mechanism changes between these temperature ranges, then the model predictions may not be accurate. In this regard, it may be useful to combine electrochemical measurements with direct observations of microstructural changes, allowing development of a realistic mechanistic model.

A number of studies have shown a growth in the size of Ni particles at temperatures ranging from 800 to $1100^{\circ} \mathrm{C}[1-3]$. Recently, transmission X-ray microscopy (TXM) was used to 
obtain three-dimensional tomographic images of $\mathrm{Ni}-\mathrm{YSZ}$ before and after accelerated thermal ageing, providing information on the structural evolution of the Ni, YSZ, and pore phases [4]. Substantial changes were observed in the $\mathrm{Ni}$ and pore phases at relatively short times and temperatures. It was concluded that such early-stage changes were mainly due to the nonequilibrated $\mathrm{Ni}$ and pore structure that forms upon reduction of $\mathrm{NiO}$, even though the initial $\mathrm{NiO}-\mathrm{YSZ}$ structure was presumably well equilibrated after high-temperature $\left(1400^{\circ} \mathrm{C}\right)$ firing. It was concluded that these changes, though important, were not reflective of the processes expected to control long-term stability.

The purpose of the present study is to evaluate changes that occur after these initial structural re-arrangements of the Ni-pore structure. The materials studied are Ni-YSZ anode functional layers (AFLs) in anode-supported SOFCs. The reduced Ni-YSZ anodes are first aged at $1100^{\circ} \mathrm{C}$ for $100 \mathrm{~h}$ in order to allow the $\mathrm{Ni}$ and pore phases to reach a reasonably well equilibrated structure. Structural and electrochemical changes of these pre-aged anodes are then observed after further ageing. TXM is utilized to obtain quantitative three-dimensional (3D) electrode microstructural images [5-9]. Electrochemical characterization is done on full cells utilizing electrochemical impedance spectroscopy (EIS) and equivalent circuit fitting to isolate the anode components of the impedance responses. The data are fit to a power-law coarsening model and used to predict long-term structural evolution and electrochemical degradation. 


\section{Experimental}

\subsection{Cell Preparation and Ageing}

Anode-supported SOFCs were prepared as described elsewhere [4, 10]. A $750 \mu \mathrm{m}$ thick dry-pressed pellet with composition 50:50 wt.\% NiO:YSZ supported a $20 \mu \mathrm{m}$ thick 50:50 wt.\% NiO:YSZ AFL and a $10 \mu \mathrm{m}$ thick YSZ electrolyte, both deposited by colloidal drop coating. No pore formers were used in the AFL. These structures were co-sintered at $1400{ }^{\circ} \mathrm{C}$ for $4 \mathrm{~h} . \mathrm{A}$ YSZ layer was then deposited on the YSZ electrolyte by screen-printing and fired at $1200{ }^{\circ} \mathrm{C}$ for $2 \mathrm{~h}$, yielding a 15-20 $\mu \mathrm{m}$ thick porous scaffold. Note that all thicknesses given above were measured after firing. All subsequent thermal treatments were done on these partial cells. Since the cathode active material was introduced later via impregnation, as discussed below, there was no need to attempt gas sealing during ageing at high temperatures, and there were no issues with cathode degradation during the treatments.

The above partial cells were heated to $8000^{\circ} \mathrm{C}$ for $3 \mathrm{~h}$ in a $4 \% \mathrm{H}_{2} / 3 \% \mathrm{H}_{2} \mathrm{O} / 93 \%$ Ar gas mixture, in order to fully reduce the $\mathrm{NiO}$ in the support and AFL. All partial cells were then aged at $1100^{\circ} \mathrm{C}$ for $100 \mathrm{~h}$. This condition was chosen, based on the results of our previous report [4], to complete the initial rearrangement of the AFL Ni-pore structure after the reduction of the $\mathrm{NiO}$. Eight partial cells were aged for the various times and temperatures listed in Table 1, while one was not aged. The latter is hereafter referred to as the "baseline" anode, while the former are indicated by their final thermal treatment condition.

After the thermal ageing, the porous YSZ scaffolds were infiltrated with a $1 \mathrm{M}$ solution containing samarium, strontium, and cobalt nitrates with amounts designed to yield the composition $\mathrm{Sm}_{0.5} \mathrm{Sr}_{0.5} \mathrm{CoO}_{3-\delta}$ (SSC) after calcination[11]. Each sample was infiltrated 8 times, resulting in a $2.5 \mathrm{mg}$ SSC deposition over the $0.5 \mathrm{~cm}^{2}$ cathode area. A silver grid was applied 
to the cathode and a $500 \mathrm{~nm}$ coat of silver was sputtered for optimal current collection. Cathode calcination was done in air at $800^{\circ} \mathrm{C}$ at the beginning of cell testing, during which time the anodes were maintain in humidified hydrogen to avoid any re-oxidation of the Ni. Infiltrating the cathodes after the anode ageing treatments assured that the cathodes were essentially identical, within the reproducibility limits of the infiltration process. The SSC infiltrated cathodes were shown to have a low resistance and a response located in the $10^{3}-10^{4} \mathrm{~Hz}$ range $[4,12]$, such that it was relatively straightforward to separate from the lower frequency anode responses.

\subsection{Electrochemical Characterization}

A Zahner IM6 electrochemical workstation was utilized to collect EIS data in the frequency range from $100 \mathrm{mHz}$ to $1 \mathrm{MHz}$. Cells were maintained at open circuit during the measurements. EIS testing was done prior to any electrode polarization, starting at $800{ }^{\circ} \mathrm{C}$ and reducing to $600{ }^{\circ} \mathrm{C}$. Stagnant air was at the cathodes in all cases. The anode fuel flow rate was $50 \mathrm{sccm}$, and the fuel composition was $3 \% \mathrm{H}_{2} \mathrm{O}-97 \% \mathrm{H}_{2}$ unless otherwise mentioned. In a few experiments, a different fuel composition with $3 \% \mathrm{H}_{2} \mathrm{O}, 10-97 \% \mathrm{H}_{2}$, balance Ar was utilized. After EIS measurements were completed, current-voltage characteristics were collected at $10 \mathrm{mV}$ increments from open circuit voltage to $0.4 \mathrm{~V}$.

\subsection{Structural Characterization}

TXM measurements were done on anodes after the various ageing treatments. TXM samples were prepared by focused ion beam milling to produce cylinders $\sim 35 \mu \mathrm{m}$ in diameter and $~ 80 \mu \mathrm{m}$ in height, as described elsewhere $[4,5]$. The data acquisition was done using beamline X8C, National Synchrotron Light Source, Brookhaven National Laboratory.[13] The instrument provides sub-30 nm 2D resolution with tomographic capabilities. Further details on 
this method have been previously reported $[5,9]$. Two tomography datasets were collected from each sample: one with an X-ray energy of $8300 \mathrm{eV}$, below the $\mathrm{Ni} \mathrm{K}$-edge, and the other at $8400 \mathrm{eV}$, above the Ni K-edge. The alignment of the X-ray projections was performed automatically using a capacitive sensor-based metrology system [13]. A standard Filtered Back Projection Reconstruction algorithm was used to reconstruct the 3D structure, and extract a stack of virtual cross-section slices from each tomography dataset [14]. The voxel size was $38.9 \mathrm{~nm}$ in all directions.

TXM datasets were cropped to isolate the AFL, the region of interest in this study, and select the area of highest image quality. Normalization algorithms were applied to the images to improve brightness and contrast. Simple thresholding was used to segment the images. The Ni phase was segmented from the above edge data, while the pore phase was segmented from a mathematical combination where the above-edge image was subtracted from an inverted below-edge image $[4,5]$.

Macrohomogeneous morphological information including phase volume fractions, surface areas, particle size distributions, phase connectivity, and TPB lengths, were calculated from the TXM 3D image data sets using methods described elsewhere $[5,10,15,16]$. Algorithms were written in-house for the image process programming language, Interactive Data Language (IDL). 


\section{Results}

\subsection{Microstructural Measurements}

Figure 1 provides 3D image renderings of the microstructures measured after $500 \mathrm{~h}$ ageing treatments at $1000^{\circ} \mathrm{C}, 1100^{\circ} \mathrm{C}$, and $1200^{\circ} \mathrm{C}$. Major morphological changes due to the thermal treatment are evident, particularly the larger features in the nickel phase.

Table 2 and Table 3 present a summary of the macrohomogeneous microstructural parameters derived from the $3 \mathrm{D}$ image data. For the baseline case of an $1100^{\circ} \mathrm{C} 100 \mathrm{~h}$ ageing treatment, both the current cell data and data obtained previously from an identically-prepared and aged cell [4] are presented in Table 2 and Table 3. As seen in the tables, these two AFLs have very similar microstructural characteristics; the differences give an indication of the size of sample-to-sample and measurement-to-measurement variations.

The volume fractions expected, based on the weighed Ni and YSZ amounts and the volume reduction upon reducing $\mathrm{NiO}$ to $\mathrm{Ni}$ (assuming an initially fully dense NiO-YSZ AFL layer), were $27.67 \% \mathrm{Ni}, 53.06 \% \mathrm{YSZ}$, and $19.33 \%$ pore. The measured volume fractions in Table 2 and Table 3 generally agree with these values to within $\leq 4 \%$, error levels previously observed in Ni-YSZ measured by 3D methods [15]. The one exception is the $1150^{\circ} \mathrm{C}-700 \mathrm{~h}$ sample, but given that all other samples including the $1200^{\circ} \mathrm{C}-500 \mathrm{~h}$ case showed no significant loss of pore volume, this was believed to be an outlier. These results indicate that there was no measureable Ni-YSZ sintering (i.e., pore volume reduction) under the present ageing conditions. No nickel loss was observed. The connected fraction of YSZ and Ni phases was nearly $100 \%$ in all cases, whereas pore connected fraction was typically $>95 \%$ in almost all cases. Again, the only exception was the $1150^{\circ} \mathrm{C}-700 \mathrm{~h}$ sample; its low connected pore 
fraction is presumably not a meaningful data point, as its surprisingly low pore volume fraction was taken to be an outlier.

Tortuosity values, computed for all phases as described elsewhere,[17] were in the ranges expected based on prior results[4] and did not vary significantly with ageing treatments: $\sim 1.6$ for $\mathrm{Ni}, \sim 1.1$ for $\mathrm{YSZ}$, and $~ 1.8$ for pores.

Figure 2 shows feature size distributions in the $\mathrm{Ni}, \mathrm{YSZ}$, and pore networks, obtained using the method described by Holzer et al.[18]. The results indicate that no major coarsening occurs below $1100^{\circ} \mathrm{C}$. The $\mathrm{YSZ}$ phase feature size increased only at the highest temperatures and times, from a average size of $\sim 500 \mathrm{~nm}$ to as much as $\sim 700 \mathrm{~nm}$. The Ni phase began coarsening at lower time and temperature than the YSZ phase, with the average size increasing from an initial value of $\sim 650 \mathrm{~nm}$ up to $\sim 950 \mathrm{~nm}$. The pore network also coarsened with increasing time and temperature, from an average size of $\sim 400 \mathrm{~nm}$ to $\sim 550 \mathrm{~nm}$. Note that the $1150^{\circ} \mathrm{C}-700 \mathrm{~h}$ case does not fit the trend well, probably because it exhibited a surprisingly low pore volume fraction. The results in Figure 2 generally agree with phase specific surface areas shown in Table 2 and Table 3, which decreased with increasing ageing temperature and time, with some scatter in the measured values.

Figure 3 (a), (b) and (c) shows 3D image representations of the TPB lines in AFLs aged at different temperatures. The image volumes shown are same as those shown in Figure 1. There is an obvious decrease in the density of TPB lines with increasing ageing temperature, as expected because of the general increasing in phase network feature sizes. Only a small fraction of the TPB lines are electrochemically inactive (indicated in red), resulting from the small fraction of isolated pores. Figure 3 (d) and (e) shows that there is a continuous decrease 
in the total and electrochemically-active TPB line densities. The active TPB density is slightly lower, due to the isolated pores, but follows the same trend.

\subsection{Electrochemical Measurements}

Figure 4 presents the current-voltage characteristics of cells with as-reduced and aged anodes, measured at $750^{\circ} \mathrm{C}$. Open circuit voltages were $\sim 1.05 \mathrm{~V}$, slightly below the theoretical value of $1.1 \mathrm{~V}$, as typically observed in this test setup utilizing Ag gas seals [4]. The cells exhibit a slight activated behavior at low current density, and an indication of concentration polarization at high current density. The peak power densities $>1 \mathrm{~W} / \mathrm{cm}^{2}$ indicate that both the anode and cathode yielded reasonably low polarization resistance, comparable to state of the art anode-supported SOFCs[9, 19]. The cell performance variation with anode ageing is not large, although there is a trend toward higher resistance and lower power density for cells with aged anodes. These trends do not follow the order of increasing ageing time and temperature, presumably due to cell-to-cell variations. Since variations in all of the cell components can impact overall cell performance, current-voltage curves are not the best way to observe effects of anode ageing. Rather, EIS measurements can isolate specific anode components of cell resistance, thereby providing a clearer indication of how ageing affects anode performance.

Figure 5 presents typical Nyquist and Bode plots of the EIS data, for the cell with the baseline anode, measured at $750^{\circ} \mathrm{C}$. As in prior measurements on similar cells, the EIS data shows visual evidence of four different responses [4, 20-22]. As in that prior report, the present EIS spectra were fitted with an equivalent circuit containing four R-CPE elements in series with a resistor, presented in Figure 5. The responses were associated with the following processes [4]. The high frequency response arises from the cathode, while the low frequency response may be related to gas conversion [20] or gas diffusion through the anode support [21]. The 
response at 1 to $10 \mathrm{~Hz}$ arises from gas diffusion in the anode, while the response centered at 100 to $1000 \mathrm{~Hz}$ arises from a charge transfer process.

The testing scheme reported previously [4] was used here to help isolate the two anode responses. One set of EIS measurements were done at a relatively high temperature and low $\mathrm{pH}_{2}$, conditions that tend to make gas diffusion concentration polarization rate limiting; as shown in Figure 6 (a), the gas diffusion response was dominant. This response resistance did not change much with anode ageing, although it was larger for the lower ageing temperatures. Another set of EIS measurements were done at low temperature and high $\mathrm{pH}_{2}$, conditions that tended to make charge-transfer processes rate limiting; as shown in Figure 6 (b), the chargetransfer response was dominant. This response resistance generally increased with increasing ageing time and temperature, except for the cell with the $1100^{\circ} \mathrm{C}-500 \mathrm{~h}$ aged anode, which showed a resistance similar to the baseline cell. There was a shift to lower frequency as the resistance increased, as expected. Note that the peak at $\sim 10^{4} \mathrm{~Hz}$ did not evolve much with anode ageing in these figures, as expected since it is attributed to the cathode that was identical on all cells.

\section{Discussion}

The present microstructural results show a number of clear trends of thermal ageing, including increases in the feature sizes of the YSZ, Ni, and pore phases, and decreases in TPB density. Figure 7 shows plots of the average Ni and YSZ sizes, and Figure 8 (a) shows the measured TPB densities, versus ageing time. In the electrochemical data, the polarization resistance associated with anode charge transfer clearly increases with increasing ageing time. The resistance data are plotted versus time in Figure 8 (c). The decreases in TPB density appear to explain the increases in charge-transfer polarization resistance, as discussed 
previously. Although there are also changes in anode concentration polarization resistance, these are not discussed further here as they were discussed previously [4] and they presumably relate more to changes in the thick anode support versus the thin AFL that was microstructurally characterized here.

In the following, a model for coarsening of composite materials is applied to quantify feature size changes, and these are related to TPB densities, using a geometrical model. The resulting predicted changes in anode structure are then used in a microstructure-based electrochemical model to predict changes in anode charge-transfer polarization resistance. In this way, it will be seen if each of the changes incurred by ageing can be explained quantitatively, and if they are all consistent. The overall model is then used to make predictions of anode ageing at nominal SOFC operating temperatures and long times. The expected accuracy of these predictions is discussed based on the quality of the present accelerated ageing data and the model fits to the data.

\subsection{Coarsening Model}

Changes in the characteristic length scale $l$ of features in a composite material can normally be fit with a power law in time $t$ :

$$
\mathbf{l}^{\mathrm{n}}-\mathbf{l}_{0}^{\mathrm{n}}=\mathbf{K}_{\mathrm{D}} \mathbf{t}
$$

where $l_{0}$ is the initial length scale, and $K_{D}$ is a mass transport coefficient. In the present case, vapor transport is not expected - Ni vapor transport has been reported at high temperature, but only at high steam partial pressures[23]. Furthermore, the presence of porosity allows surface diffusion, which is generally much faster than bulk diffusion. Thus, $K_{D}$ is a surface diffusion coefficient with the form[24]: 


$$
\mathrm{K}_{\mathrm{D}}=\mathrm{K}_{\mathrm{D}, 0} \mathrm{e}^{-\mathrm{E}_{\mathrm{A}} / \mathrm{k}_{\mathrm{B}} \mathrm{T}}
$$

where $E_{A}$ is the surface diffusion activation energy, $K_{D, 0}$ is the pre-factor, $k_{B}$ is the Boltzmann constant, and $\mathrm{T}$ is the temperature. For surface diffusion, the exponent in eq. 1 is expected to be $n=4$. [25] In this case, the time-dependent length scale can be written as:

$$
\mathrm{l}=l_{0}\left(1+\mathrm{l}_{0}^{-4} \mathrm{~K}_{\mathrm{D}, 0} \mathrm{te}^{-\mathrm{E}_{\mathrm{A}} / \mathrm{k}_{\mathrm{B}} \mathrm{T}}\right)^{1 / 4}
$$

An algorithm based on the a least median of square regression[26, 27] was used to fit eq. 3, with $K_{D, 0}, E_{A}$ as fitting parameters, to the Ni and $Y S Z$ average particle size experimental data. Given the small number of data points, the $80^{\text {th }}$ percentile was minimized instead of the median.[28] Different $n$ values were tried, and while there is insufficient data to provide a definitive result, it appears that $n=4$ is a reasonable choice. The best fits to the feature size data, represented as black curves in Figure 7, have coefficients of determination $\mathrm{R}^{2}$ of 0.957 for $\mathrm{Ni}$ and 0.940 for $\mathrm{YSZ}$. However, based on the limited number of data points and the scatter in the data relative to the fits, which presumably arises due to sample-to-sample variations and measurement error, there is a range of fits of reasonable quality. The range of predicted values, shown in Figure 7 as shaded regions, correspond to a decrease of 0.004 in $R^{2}$ (a $5 \%$ 。 increase in the deviation of $R^{2}$ from an ideal value of 1 ) and yield the following ranges of fitted values:

$$
\begin{gathered}
1.48 \times 10^{-19} \leq K_{D, 0}^{N i} \leq 4.59 \times 10^{-18} \mathrm{~m}^{4} \cdot \mathrm{h}^{-1} \\
2.33 \leq E_{A}^{N i} \leq 2.76 \mathrm{eV} \\
5.38 \times 10^{-19} \leq K_{D, 0}^{Y S Z} \leq 2.17 \times 10^{-17} \mathrm{~m}^{4} \cdot \mathrm{h}^{-1} \\
2.64 \leq E_{A}^{Y S Z} \leq 3.09 \mathrm{eV}
\end{gathered}
$$


The predicted size ranges tend to grow larger at temperatures and times increasingly far the measured range.

The density of TPB lines can be related to particle size using geometrical spherepacking models of composite electrodes[29-31] For the present case where the average YSZ particle size is smaller than the average nickel particle size[30, 31]:

$$
\mathrm{d}_{\mathrm{TPB}}=\mathrm{A} \frac{l^{Y S Z}}{\left(\mathrm{l}^{N i}\right)^{3}}
$$

where $A$ is a constant that depends on the details of the geometry. Combining Eqs. 1 - 3 with $n$ $=4$, and defining $\mathrm{A}$ based on the initial conditions at $\mathrm{t}=0, \mathrm{~A}=\mathrm{d}_{\mathrm{TPB}}^{0} \frac{\left(l_{0}^{N i}\right)^{3}}{l_{0}^{Y S Z}}$ yields:

$\mathrm{d}_{\mathrm{TPB}}=\mathrm{d}_{\mathrm{TPB}}^{0} \frac{\left(1+l_{0}^{Y S Z^{-\mathrm{n}}} K_{D, 0}^{Y S Z} \mathrm{te}^{-E_{A}^{Y S Z} / \mathrm{k}_{\mathrm{B}} \mathrm{T}}\right)^{1 / n}}{\left(1+l_{0}^{N i}{ }^{-\mathrm{n}} K_{D, 0}^{N i} \mathrm{te}^{-E_{A}^{N i} / \mathrm{k}_{\mathrm{B}} \mathrm{T}}\right)^{3 / n}}$

Figure 8 (a) presents how the model prediction fits the experimental TPB data. The values from the fits shown in Figure 7 were used in eq. 5, with only the initial TPB length as a fitting parameter, to obtain the predicted TPB density versus time curves shown. The fitted value is $\mathrm{d}_{\mathrm{TPB}}^{0}=2.29 \mu \mathrm{m}^{-2}$. The predicted ranges are relatively large because they combine the ranges of both the Ni and YSZ particle sizes. The trend and magnitude of the TPB density changes predicted by the model match reasonably well with the experimental data. Since the TPB calculation uses the particle sizes, this indicates that the particles size increases in Figure 7 are consistent with the decreases in TPB density in Figure 8 (a). Note that the deviations between the measured values and the predictions are larger than in the particle size data; this 
may indicate that the 3D reconstruction TPB density values are less accurate than the particle size values.

\subsection{Prediction of anode polarization resistance}

A transmission line model [32] is used to relate the charge transfer portion of the anode polarization resistance $\mathrm{R}_{\mathrm{ct}}^{\mathrm{AS}}$ to the measured TPB density:

$$
\mathrm{R}_{\mathrm{ct}}^{\mathrm{AS}}=\sqrt{\frac{\mathrm{R}_{\mathrm{LS}}}{\sigma_{\mathrm{Ion}} \mathrm{d}_{\mathrm{TPB}}}} \operatorname{coth}\left(L \sqrt{\frac{d_{T P B}}{\sigma_{i o n} R_{L S}}}\right)
$$

where $\sigma_{\text {lon }}$ is the effective ionic conductivity of the YSZ phase in the Ni-YSZ, $L$ is the anode thickness, and $R_{L S}$ is the TPB line-specific resistance. In the limit where the anode is much thicker than the utilization length, which should be satisfied in the present cells given that the total anode thickness including support is $~ 700 \mu \mathrm{m}$, the coth term goes to unity. Substituting eq. 5 into this simplified form of eq. 6 yields an expression for the time dependence of the resistance:

$$
\mathrm{R}_{\mathrm{ct}}^{\mathrm{AS}}=\sqrt{\frac{\mathrm{R}_{\mathrm{LS}}}{\sigma_{\mathrm{Ion}} \mathrm{d}_{\mathrm{TPB}}^{0}} \frac{\left(1+l_{0}^{N i}{ }^{-\mathrm{n}} K_{D, 0}^{N i} \mathrm{te}^{-E_{A}^{N i} / \mathrm{k}_{\mathrm{B}} \mathrm{T}}\right)^{3 / 2 n}}{\left(1+l_{0}^{Y S Z^{-\mathrm{n}}} K_{D, 0}^{Y S Z} \mathrm{te}^{-E_{A}^{Y S Z} / \mathrm{k}_{\mathrm{B}} \mathrm{T}}\right)^{1 / 2 n}}}
$$

The transmission-line model does not account for gas diffusion, so eq. 7 is compared with the charge-transfer portion of the anode polarization resistance in Figure 8 (b), i.e., with the gas diffusion component removed. $R_{L S}$ was used as a fitting parameter, and the fitting was done using the same method as fits described above. $R_{L S}=1.5 \times 10^{5} \Omega . \mathrm{cm}$ was obtained, and the resulting fits are show in Figure 8 (b). This fitted $R_{L S}$ value is in the range expected for $\mathrm{Ni}$ YSZ TPBs at $600^{\circ} \mathrm{C}$ [33]. There is considerable scatter in the data relative to the fitted curves, 
presumably due to a combination of sample-to-sample variations and measurement errors. Nonetheless, the model correctly predicts the overall trend and the magnitude of the $\mathrm{R}_{\mathrm{ct}}^{\mathrm{AS}}$ increases.

\subsection{Model Predictions}

Figure 7, 8 (a) and 8 (b) are plotted with a $\log ($ time) horizontal scale, in order to show model predictions for Ni and YSZ feature size, TPB density, and $\mathrm{R}_{\mathrm{ct}}^{\mathrm{AS}}$ out to $100,000 \mathrm{~h}$ on the same plots with the shorter-time accelerated test data. Over long-term operation $(100,000 \mathrm{~h})$ at $800^{\circ} \mathrm{C}$, the changes in these quantities are relatively small. The particle size increases predicted for both phases at $800^{\circ} \mathrm{C}$, a common SOFC operating temperature, are at most $\sim 10 \%$, and even smaller at lower temperature. At $800^{\circ} \mathrm{C}$, a decrease in the total TPB density of $\sim 15-45 \%$ is predicted over 100,000 hours. This drops to $\sim 3-9 \%$ if the operating temperature is reduced to $750^{\circ} \mathrm{C}$ and $\sim 0.5-6 \%$ at $700^{\circ} \mathrm{C}$.

The present results represent only one possible Ni-YSZ microstructure out of a wide range of possibilities; variables include $\mathrm{Ni}, \mathrm{YSZ}$, and pore volume fractions, particle size distributions, etc. Each of these cases will presumably have different long-term durabilities, so it will be important to compare coarsening effects in different Ni-YSZ microstructures [34] and use them to develop a more facile model that includes such effects. Note that the present case has a relatively high YSZ volume fraction with relatively low $\mathrm{Ni}$ and pore volume fractions, such that Ni coarsening is highly constrained by the large volume fraction of YSZ. This perhaps explains why the increases in Ni feature size are only slightly greater than those for YSZ, despite the much lower melting point of Ni relative to YSZ. The present anodes have relatively large feature sizes due to the high firing temperature, which also leads to relatively slow 
coarsening. Thus, other Ni-YSZ microstructures with higher Ni and pore volume fractions, and/or smaller feature sizes, are expected to show faster Ni coarsening.

The present model predicts that smaller Ni-YSZ feature sizes should give rise to much faster coarsening and thereby faster degradation. To illustrate this point, here we assume the same $\mathrm{Ni}$-YSZ structure as the present anodes but with sizes scaled down by a factor of 4 , such that initial feature sizes are $\sim 150 \mu \mathrm{m}$, and the initial TPB density is $\sim 56 \mu \mathrm{m}^{-2}$ [35]. Figure 8 (c) shows the predicted decrease in TPB density versus time at different temperatures. The degradation rate at $800^{\circ} \mathrm{C}$ is much larger than in Figure $8(a)$, due to the smaller starting feature size. However, these high-TPB-density Ni-YSZ anodes would be designed to operate at lower temperatures of $\sim 600^{\circ} \mathrm{C}$. Indeed, SOFCs with such anode structure have shown very good electrochemical performance at $600^{\circ} \mathrm{C}[35]$. At this temperature, the predicted degradation is quite low even up to $100,000 \mathrm{~h}$.

Besides the fitting uncertainty discussed above, there is also the possibility that the structural evolution mechanism may change between from the present accelerated degradation regime $-1000-1200^{\circ} \mathrm{C}$ for $<1000 \mathrm{~h}-$ and SOFC operating conditions -700 $850^{\circ} \mathrm{C}$ for up to $100,000 \mathrm{~h}$. Note that only coarsening, not sintering, was observed in the present experiments. Given that sintering typically has a higher activation energy than coarsening,[36] this should continue to be the case down to SOFC operating temperatures. However, the cation transport mechanism associated with coarsening could potentially change, thereby introducing additional errors in extrapolating the accelerated test data.

Experiments can be suggested to provide additional data that can reduce the error ranges in the present model, thereby allowing more definitive predictions. For example, it would be useful to carry out repeated TXM measurements with intervening annealing steps 
[37] up to $10,000 \mathrm{~h}$. Such a measurement at two temperatures, e.g., 1000 and $900^{\circ} \mathrm{C}$, should provide measurable changes in feature size and TPB density, thereby substantially reducing the present error ranges.

\section{Summary and Conclusions}

Morphological changes during accelerated ageing of Ni-YSZ AFLs were investigated using transmission X-ray microscopy (TXM), and properties were characterized using electrochemical impedance spectroscopy (EIS). Measured Ni and YSZ feature size increases with time were both fit well with a power-law coarsening model; the Ni coarsening rate was only slightly faster than that of YSZ, indicating that the YSZ structure limited Ni coarsening. Measured decreases in TPB density were found to be consistent with the power-law feature size variations, by comparing the two using a geometrical TPB model. The anode chargetransfer polarization resistance increase with time, calculated using the TPB density variation in a transmission-line electrochemical model, agreed reasonably well with the measured resistance increases. That is, all the observed changes with accelerated anode ageing were consistent with the power-law coarsening model.

When the above accelerated-test model is used to predict the degradation of anodes under normal SOFC operating conditions, i.e., at $\sim 800^{\circ} \mathrm{C}$ for up to $100,000 \mathrm{~h}$, the degradation appears to relatively small. For example, the best fit predicts a decrease in TPB density of only $\sim 20 \%$, and a corresponding increase in charge-transfer polarization resistance of $\sim 10 \%$, over $100,000 \mathrm{~h}$. However, based on data scatter and the limited number of data points, there is considerable variation in the predictions; thus, the degradation may actually be greater. Furthermore, different Ni-YSZ microstructures and compositions, along with higher steam 
content in the fuel, may yield substantially faster degradation. Thus, there is a need to carry out additional life testing of the present anodes, particularly longer-term tests at lower temperature, in order to allow more accurate model predictions. In addition, systematic studies of how different Ni-YSZ structures degrade under different fuel compositions are needed. Degradation rates for anodes with much higher TPB densities, i.e., smaller feature sizes, are predicted to be much faster at $800^{\circ} \mathrm{C}$, but are acceptably small at $600^{\circ} \mathrm{C}$.

\section{Acknowledgments}

The authors gratefully acknowledge financial support from the Global Climate and Energy Project at Stanford University Project under award 51922 and the National Science Foundation under grant numbers DMR-0907639 and DMR-1506925. Use of the National Synchrotron Light Source, Brookhaven National Laboratory, was supported by the U.S. Department of Energy, Office of Science, Office of Basic Energy Sciences, under Contract No. DE-AC02-98CH10886.

\section{References}

[1] D. Simwonis, F. Tietz, D. Stover, Solid State Ionics, 132 (2000) 241-251.

[2] A. Faes, A. Hessler-Wyser, D. Presvytes, C.G. Vayenas, J. Van Herle, Fuel Cells, 9 (2009) 841-851.

[3] P. Tanasini, M. Cannarozzo, P. Costamagna, A. Faes, J. Van Herle, A. Hessler-Wyser, C. Comninellis, Fuel Cells, 9 (2009) 740-752.

[4] D. Kennouche, Y.C.K. Chen-Wiegart, J.S. Cronin, J. Wang, S. Barnett, Journal of The Electrochemical Society, 160 (2013) F1293-F1304.

[5] Y.C.K. Chen-Wiegart, J.S. Cronin, Q.X. Yuan, K.J. Yakal-Kremski, S.A. Barnett, J. Wang, Journal of Power Sources, 218 (2012) 348-351.

[6] P.R. Shearing, J. Gelb, J. Yi, W.K. Lee, M. Drakopolous, N.P. Brandon, Electrochemistry Communications, 12 (2010) 1021-1024.

[7] V. Julie, L. Jerome, C. Peter, B. Pierre, D. Gerard, S. Heikki, U.V. Francois, Journal of Power Sources, 243 (2013) 841-849.

[8] K. Yakal-Kremski, J.S. Cronin, Y.C.K. Chen-Wiegart, J. Wang, S.A. Barnett, Fuel Cells, 13 (2013) $449-454$. 
[9] J.S. Cronin, Y.C.K. Chen-Wiegart, J. Wang, S.A. Barnett, Journal of Power Sources, 233 (2013) 174-179.

[10]J.S. Cronin, J.R. Wilson, S.A. Barnett, Journal of Power Sources, 196 (2011) 2640-2643.

[11]J.D. Nicholas, S.A. Barnett, Journal of the Electrochemical Society, 157 (2010) B536-B541.

[12] S.-W. Baek, J. Bae, Y.-S. Yoo, Journal of Power Sources, 193 (2009) 431-440.

[13]J. Wang, Y.C.K. Chen, Q.X. Yuan, A. Tkachuk, C. Erdonmez, B. Hornberger, M. Feser, Applied Physics Letters, 100 (2012).

[14]F. Natterer, The Mathematics of Computerized Tomography, in: The Mathematics of Computerized Tomography, Society for Industrial and Applied Mathematics, 2001.

[15]J.S. Cronin, K. Muangnapoh, Z. Patterson, K.J. Yakal-Kremski, V.P. Dravid, S.A. Barnett, Journal of the Electrochemical Society, 159 (2012) B385-B393.

[16]J.R. Wilson, J.S. Cronin, A.T. Duong, S. Rukes, H.Y. Chen, K. Thornton, D.R. Mumm, S. Barnett, Journal of Power Sources, 195 (2010) 1829-1840.

[17] Y.C.K. Chen-Wiegart, R. DeMike, C. Erdonmez, K. Thornton, S.A. Barnett, J. Wang, Journal of Power Sources, 249 (2014) 349-356.

[18]L. Holzer, B. Iwanschitz, T. Hocker, B. Munch, M. Prestat, D. Wiedenmann, U. Vogt, P. Holtappels, J. Sfeir, A. Mai, T. Graule, Journal of Power Sources, 196 (2011) 1279-1294.

[19]J.R. Wilson, M. Gameiro, K. Mischaikow, W. Kalies, P.W. Voorhees, S.A. Barnett, Microscopy and microanalysis : the official journal of Microscopy Society of America, Microbeam Analysis Society, Microscopical Society of Canada, 15 (2009) 71-77.

[20] S. Primdahl, M. Mogensen, Journal of the Electrochemical Society, 145 (1998) 2431-2438.

[21]A. Leonide, A. Weber, E. Ivers-Tiffée, in, The Electrochemical Society, 2010, pp. 1183-1183.

[22] S.H. Jensen, J. Hjelm, A. Hagen, M. Mogensen, (2010).

[23] A. Hagen, R. Barfod, P.V. Hendriksen, Y.-L. Liu, S. Ramousse, Journal of The Electrochemical Society, 153 (2006) A1165.

[24]D.A. Porter, K.E. Easterling, Phase Transformations in Metals and Alloys, (Revised Reprint), CRC press, 2011.

[25]B.K. Chakraverty, Journal of Physics and Chemistry of Solids, 28 (1967) 2401-2412.

[26]P.J. Rousseeuw, Journal of the American Statistical Association, 79 (1984) 871.

[27]P.J. Rousseeuw, M. Hubert, Wiley Interdisciplinary Reviews: Data Mining and Knowledge Discovery, 1 (2011) 73-79.

[28]R. Koenker, Quantile regression, Cambridge university press, 2005.

[29] W. Zhu, D. Ding, C. Xia, Electrochemical and Solid-State Letters, 11 (2008) B83.

[30]D. Chen, Z. Lin, H. Zhu, R.J. Kee, Journal of Power Sources, 191 (2009) 240-252.

[31]D. Chen, L. Lu, J. Li, Z. Yu, W. Kong, H. Zhu, Journal of Power Sources, 196 (2011) 3178-3185.

[32] A. Utz, J. Joos, A. Weber, E. Ivers-Tiffée, (2011) 1669-1682.

[33]W.G. Bessler, M. Vogler, H. Stormer, D. Gerthsen, A. Utz, A. Weber, E. Ivers-Tiffee, Physical chemistry chemical physics : PCCP, 12 (2010) 13888-13903.

[34] Y.C.K. Chen-Wiegart, D. Kennouche, J.S. Cronin, S. Barnett, J. Wang, in preparation, (2015).

[35]D. Kennouche, J. Hong, H.S. Noh, J.W. Son, S.A. Barnett, Physical chemistry chemical physics : PCCP, 16 (2014) 15249-15255.

[36] M.N. Rahaman, Ceramic Processing and Sintering, Taylor \& Francis, 2003.

[37]D. Kennouche, Y.C.K. Chen-Wiegart, K. Yakal-Kremski, J. Wang, J. Gibbs, P.W. Voorhees, S. Barnett, in preparation, (2015). 
Figure 1: 3D image renderings of the Ni-YSZ AFL microstructures measured after $500 \mathrm{~h}$ ageing at $1000^{\circ} \mathrm{C}(\mathrm{a}), 1100^{\circ} \mathrm{C}(\mathrm{b})$ and $1200^{\circ} \mathrm{C}$ (c). These images show small but representative portions of the larger imaged volumes.

Figure 2: Normalized size distributions of the YSZ, Ni and pore phases after ageing at different temperatures for 500 hours $\left(a, c\right.$, and e) and for different times at $1150^{\circ} \mathrm{C}(b, d$, and f).

Figure 3: 3D image renderings showing the TPB lines in AFLs aged for $500 \mathrm{~h}$ at $1000^{\circ} \mathrm{C}$ (a), $1100^{\circ} \mathrm{C}$ (b) and $1200^{\circ} \mathrm{C}$ (c). Total and electroch emically-active TPB line density versus ageing temperature for $500 \mathrm{~h}(\mathrm{~d})$, and versus ageing time at $1150^{\circ} \mathrm{C}(\mathrm{e})$.

Figure 4: Potential and power density versus current density for SOFCs with anodes (a) aged at different temperatures for $500 \mathrm{~h}$ and (b) aged for different times at $1150^{\circ} \mathrm{C}$, compared with the baseline anode cell.

Figure 5: EIS data from the cell with a baseline anode (with only the initial pre-ageing step), measured at $750^{\circ} \mathrm{C}$ at OCV. Also shown are the equivalent circuit model, the best fit, and the individual circuit element components of the fit.

Figure 6: Bode and Nyquist plots of the impedance data measured at (a) high temperature and low partial $\mathrm{H} 2$ pressure $(\mathrm{pH} 2)$, and (b) low temperature and high $\mathrm{pH} 2$ for cells with differently aged anodes. Real ohmic polarization has been subtracted on the Nyquist plot in order to facilitate comparison of the polarization arcs. 
Figure 7: Nickel and YSZ average particle size versus time at different temperatures, derived from the data in Figure 2. Also shown are predictions from eq. 3: the ranges shown correspond to the range of parameters given that provide good fits to the measured data. Black lines correspond to best fit.

Figure 8: (a) Experimental TPB line density versus time for different ageing temperatures. Also shown for comparison are the model predictions using the feature size coarsening model shown in Figure 7 along with a fitted value of initial TPB line density in eq. 5 . The ranges shown correspond to the ranges of the particle size variations in Figure 7.

(b) Anode polarization resistance due to the TPB process, from fits to the impedance data measured at $600{ }^{\circ} \mathrm{C}$ (Figure $6 \mathrm{~b}$ ), versus ageing t ime at different temperatures. Also shown for comparison are the predictions using the TPB line density fits shown in (a) in the transmission line model (eq. 7). The ranges shown correspond to the ranges of the TPB density variations in (a) .

(c) Predicted TPB line density versus time for ageing temperatures from 600 to $800{ }^{\circ} \mathrm{C}$, using the present model for an anode with feature sizes 4 times smaller than the present anodes. The ranges shown correspond to the ranges of the TPB density variations discussed with regard to (a). 
Table 1: Temperatures and times utilized in the ageing study. The gas atmosphere was $4 \% \mathrm{H}_{2} / 3 \% \mathrm{H}_{2} \mathrm{O} / 93 \%$ Ar.

\begin{tabular}{cc}
\hline Pre-treatment only (Baseline) & $1100^{\circ} \mathrm{C}-100 \mathrm{~h}$ \\
\hline Varying temperature & $1100^{\circ} \mathrm{C}-100 \mathrm{~h}+1000{ }^{\circ} \mathrm{C}-500 \mathrm{~h}$ \\
& $1100^{\circ} \mathrm{C}-100 \mathrm{~h}+1050^{\circ} \mathrm{C}-500 \mathrm{~h}$ \\
& $1100^{\circ} \mathrm{C}-100 \mathrm{~h}+1100{ }^{\circ} \mathrm{C}-500 \mathrm{~h}$ \\
& $1100^{\circ} \mathrm{C}-100 \mathrm{~h}+1150^{\circ} \mathrm{C}-500 \mathrm{~h}$ \\
& $1100^{\circ} \mathrm{C}-100 \mathrm{~h}+1200{ }^{\circ} \mathrm{C}-500 \mathrm{~h}$ \\
\hline Varying time & $1100^{\circ} \mathrm{C}-100 \mathrm{~h}+1150^{\circ} \mathrm{C}-100 \mathrm{~h}$ \\
& $1100^{\circ} \mathrm{C}-100 \mathrm{~h}+1150^{\circ} \mathrm{C}-300 \mathrm{~h}$ \\
& $1100^{\circ} \mathrm{C}-100 \mathrm{~h}+1150^{\circ} \mathrm{C}-700 \mathrm{~h}$ \\
\hline
\end{tabular}


Table 2: Summary of the measured 3D structural data at constant ageing time

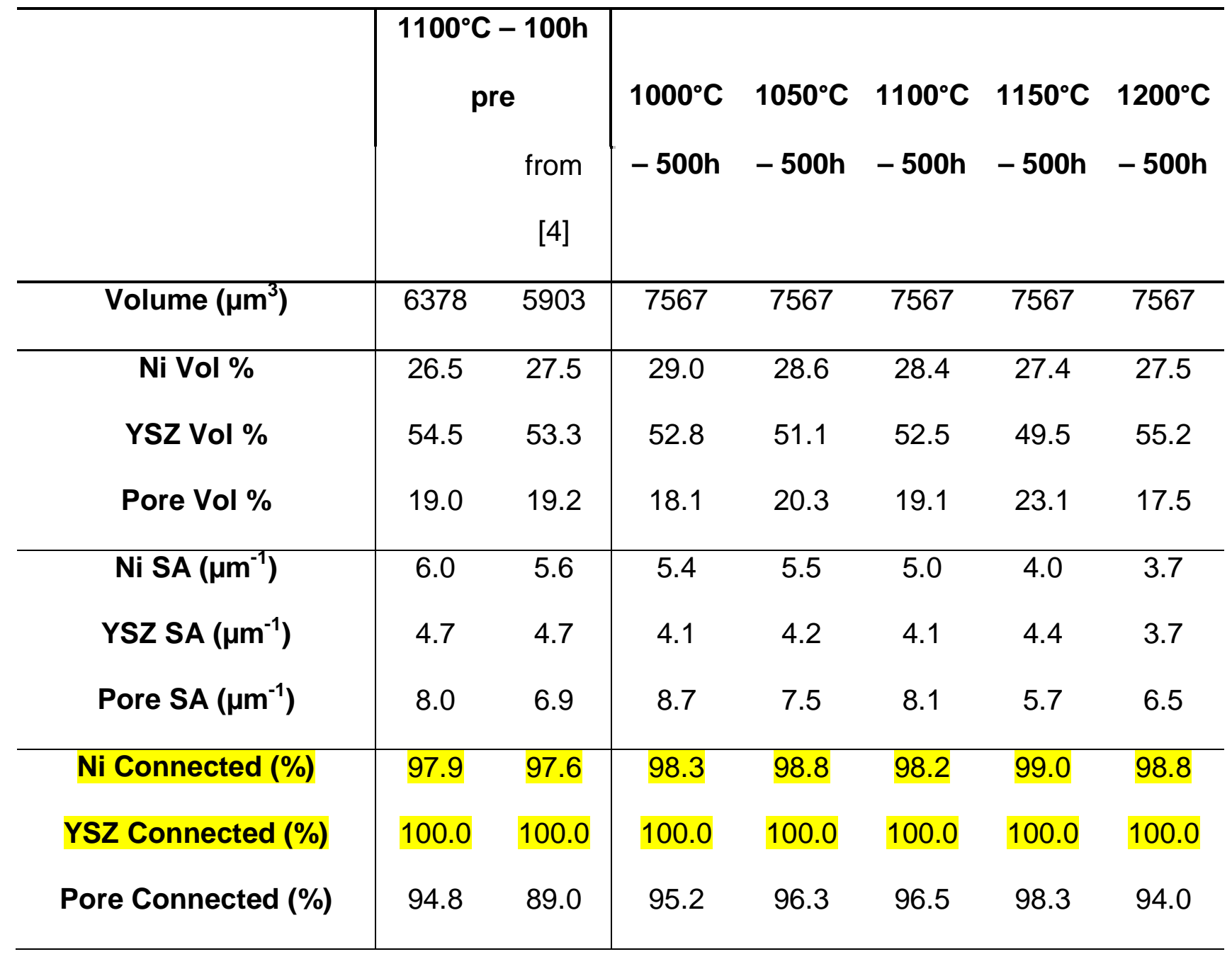


Table 3: Summary of the measured 3D structural data at fixed ageing temperature

\begin{tabular}{|c|c|c|c|c|c|c|}
\hline & $1100^{\circ}$ & $\begin{array}{l}\text { 100h } \\
\text { from [4] }\end{array}$ & $\begin{array}{l}1150^{\circ} \mathrm{C} \\
-100 \mathrm{~h}\end{array}$ & $\begin{array}{l}1150^{\circ} \mathrm{C} \\
-300 \mathrm{~h}\end{array}$ & $\begin{array}{l}1150^{\circ} \mathrm{C} \\
-500 \mathrm{~h}\end{array}$ & $\begin{array}{l}1150^{\circ} \mathrm{C} \\
-700 \mathrm{~h}\end{array}$ \\
\hline Volume $\left(\mu \mathrm{m}^{3}\right)$ & 6378 & 5903 & 6486 & 3834 & 7567 & 4973 \\
\hline Ni Vol \% & 26.5 & 27.5 & 28.6 & 27.8 & 27.4 & 27.6 \\
\hline YSZ Vol \% & 54.5 & 53.3 & 52.0 & 53.2 & 49.5 & 61.0 \\
\hline Pore Vol \% & 19.0 & 19.2 & 19.4 & 19.0 & 23.1 & 11.5 \\
\hline Ni SA $\left(\mu m^{-1}\right)$ & 6.0 & 5.6 & 5.0 & 4.6 & 4.0 & 4.0 \\
\hline YSZ SA $\left(\mu \mathrm{m}^{-1}\right)$ & 4.7 & 4.7 & 4.9 & 4.7 & 4.3 & 3.3 \\
\hline Pore SA $\left(\mu \mathrm{m}^{-1}\right)$ & 8.0 & 6.9 & 7.8 & 7.8 & 5.6 & 8.7 \\
\hline Ni Connected (\%) & 97.9 & 97.6 & 98.4 & 99.0 & 99.0 & 98.6 \\
\hline YSZ Connected (\%) & 100.0 & 100.0 & 100.0 & 100.0 & 100.0 & 100.0 \\
\hline Pore Connected & 94.8 & 89.0 & 95.5 & 96.0 & 98.3 & 78.7 \\
\hline
\end{tabular}


a)

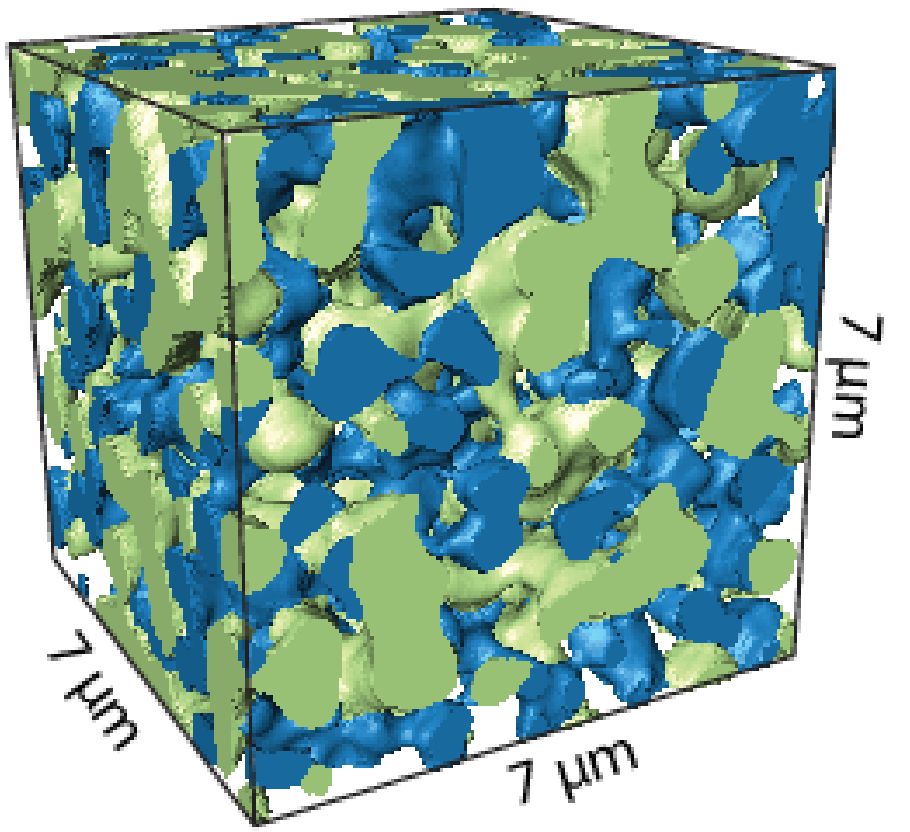

$\mathrm{Ni}$ b)

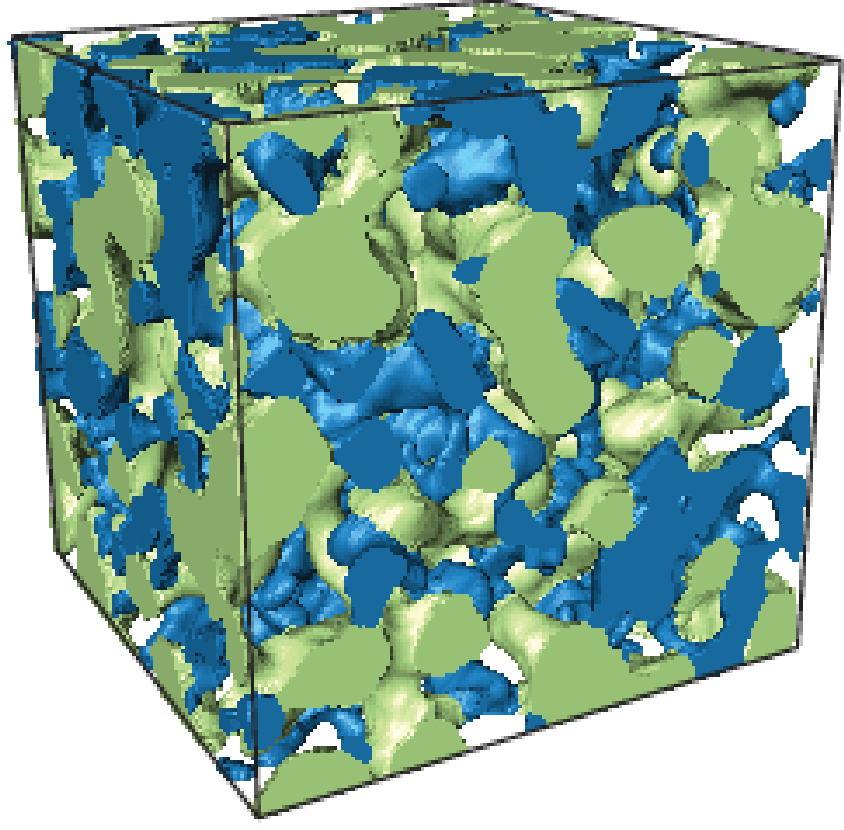

c)

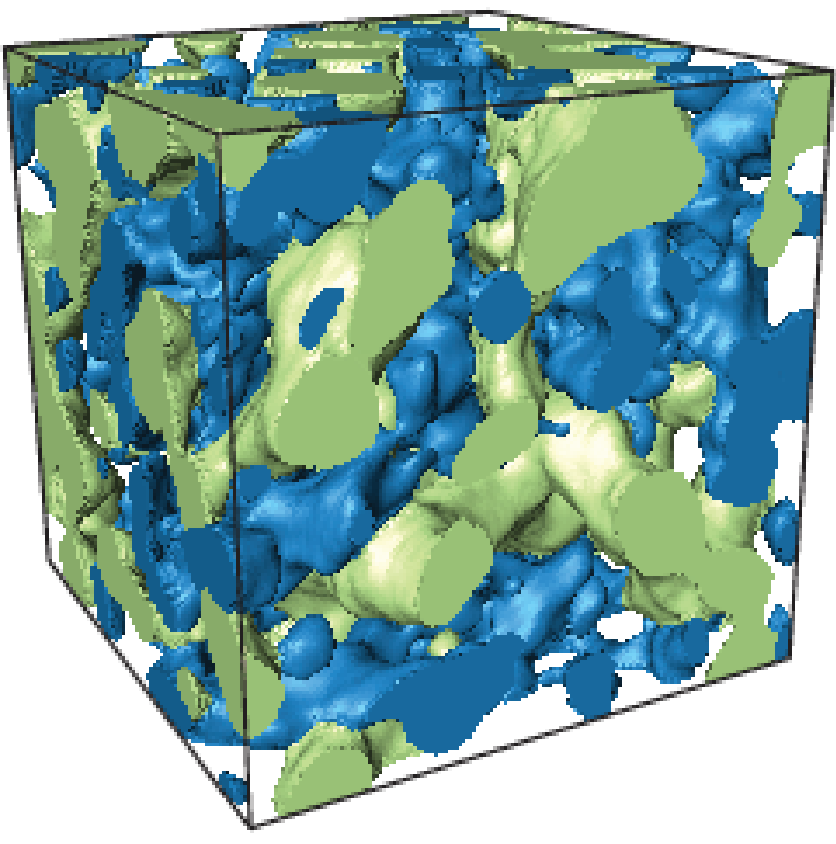

YSZ not shown 
At $500 \mathrm{~h}$

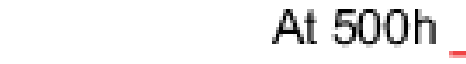

$-1000^{\circ} \mathrm{C}-600 \mathrm{~h}$ $1050^{\circ} \mathrm{C}-500 \mathrm{~h}$ 

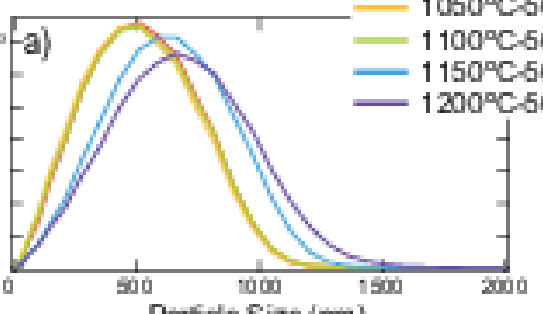

Particle Size (mm)
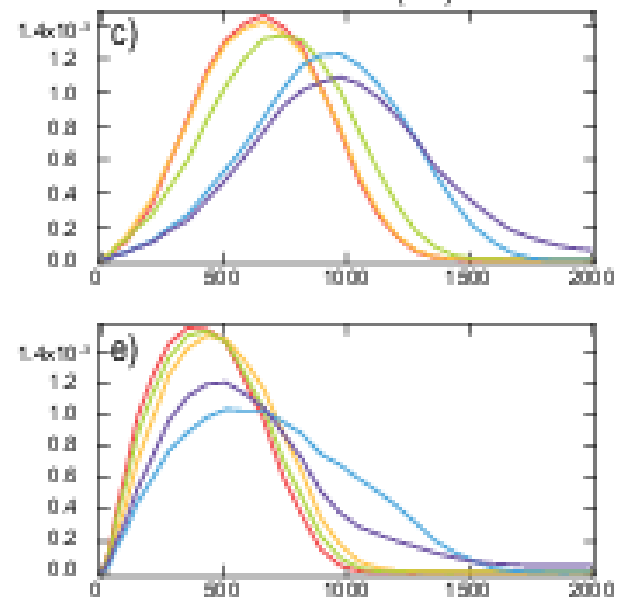

At $1150^{\circ} \mathrm{C}$
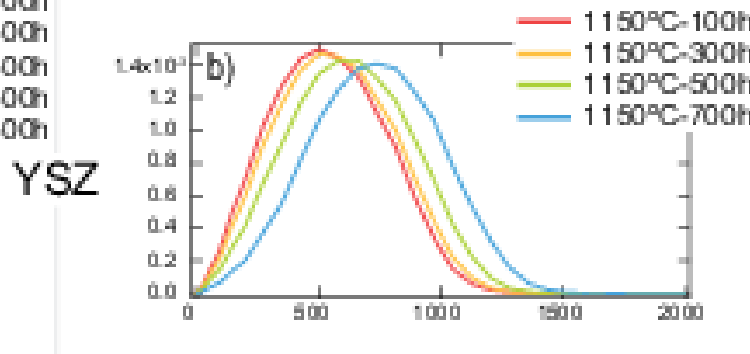

$\mathrm{Ni}$

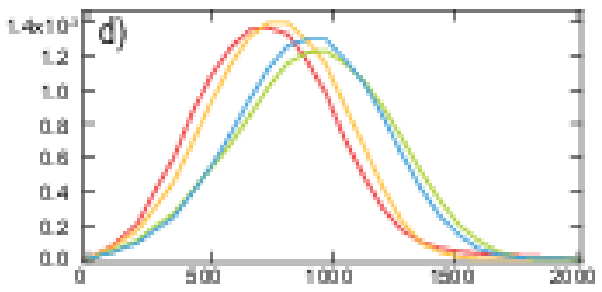

Pores

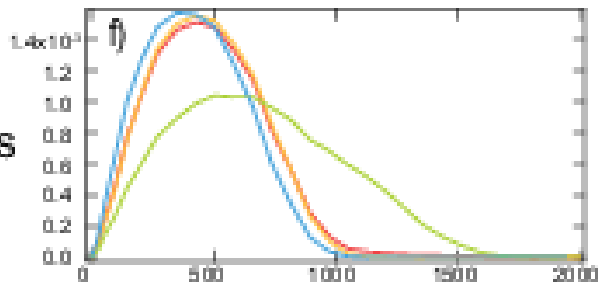


a)

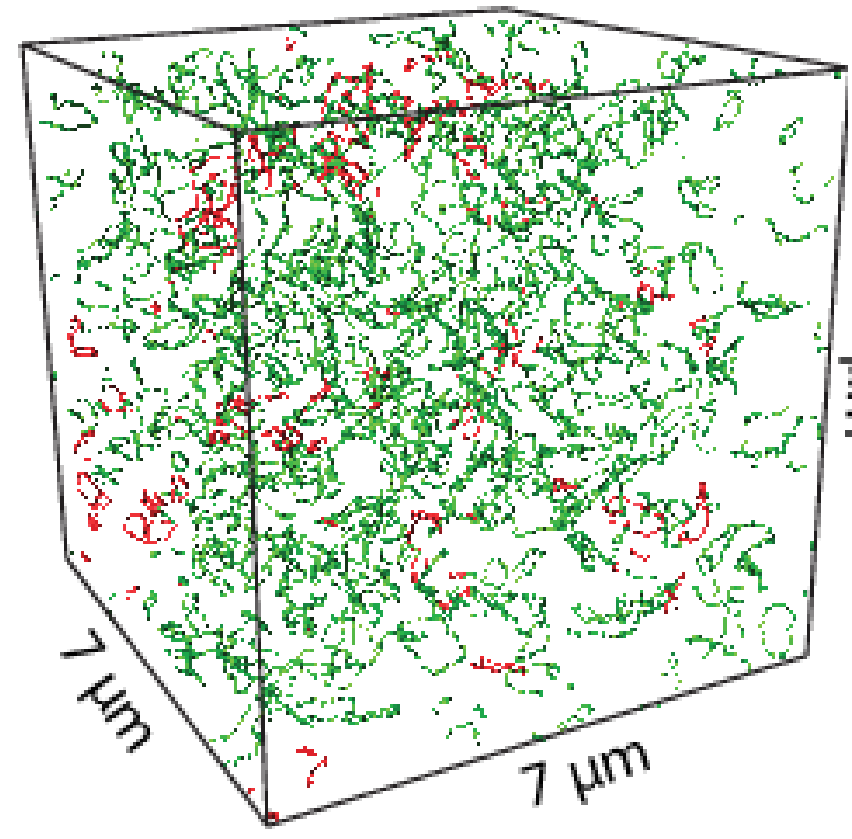

b)

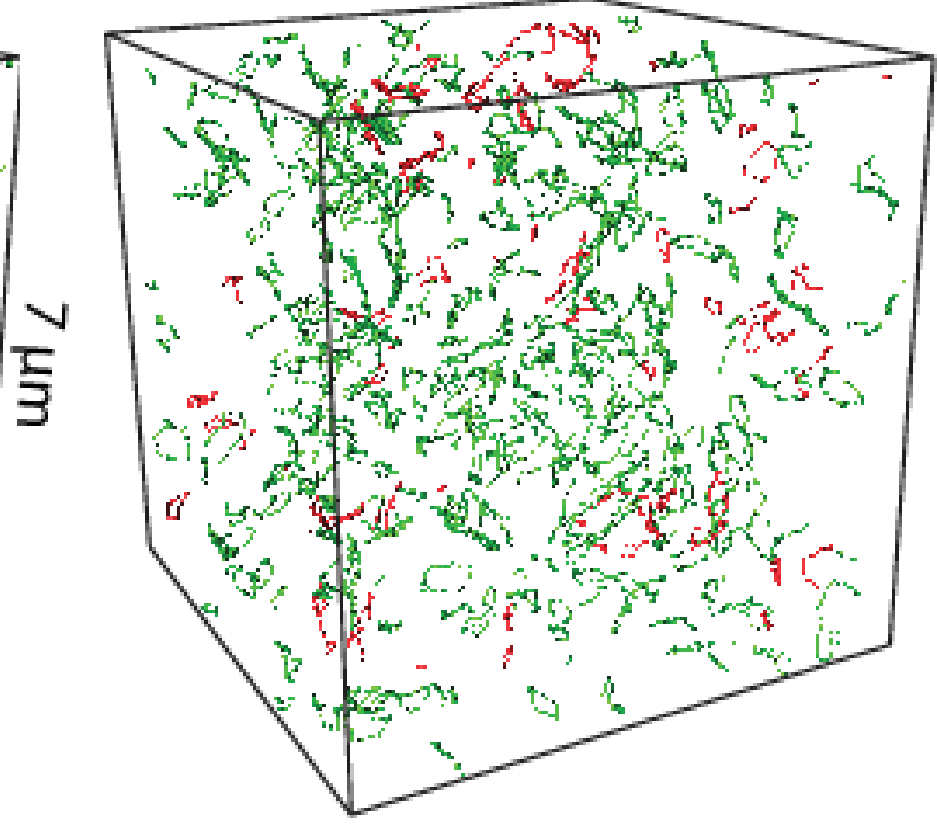

c)

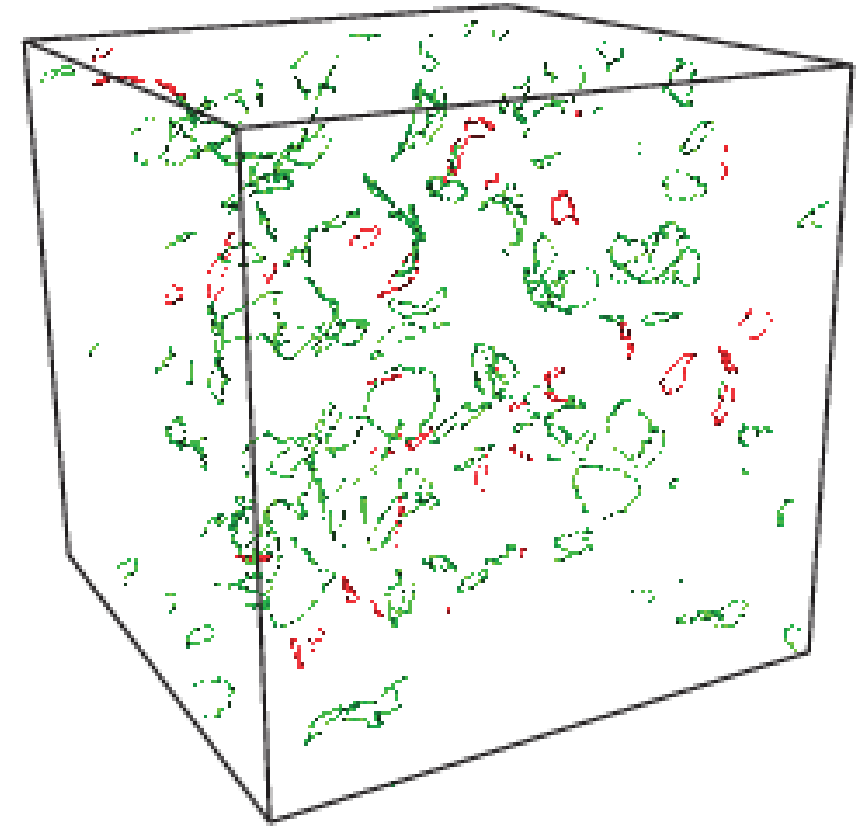

\section{Percolated $\square$ Isolated}
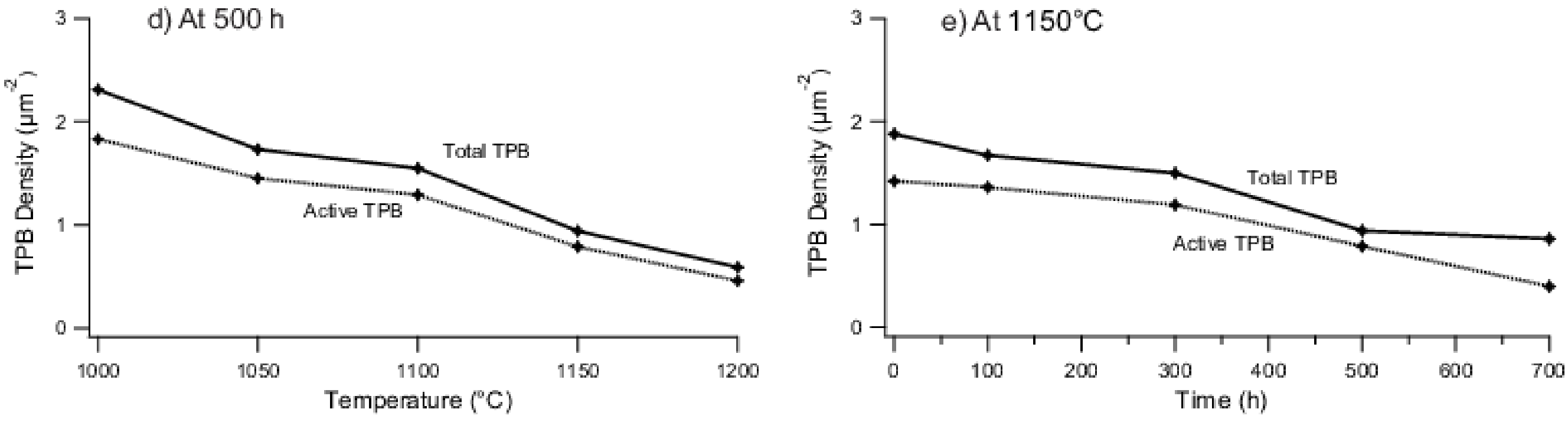

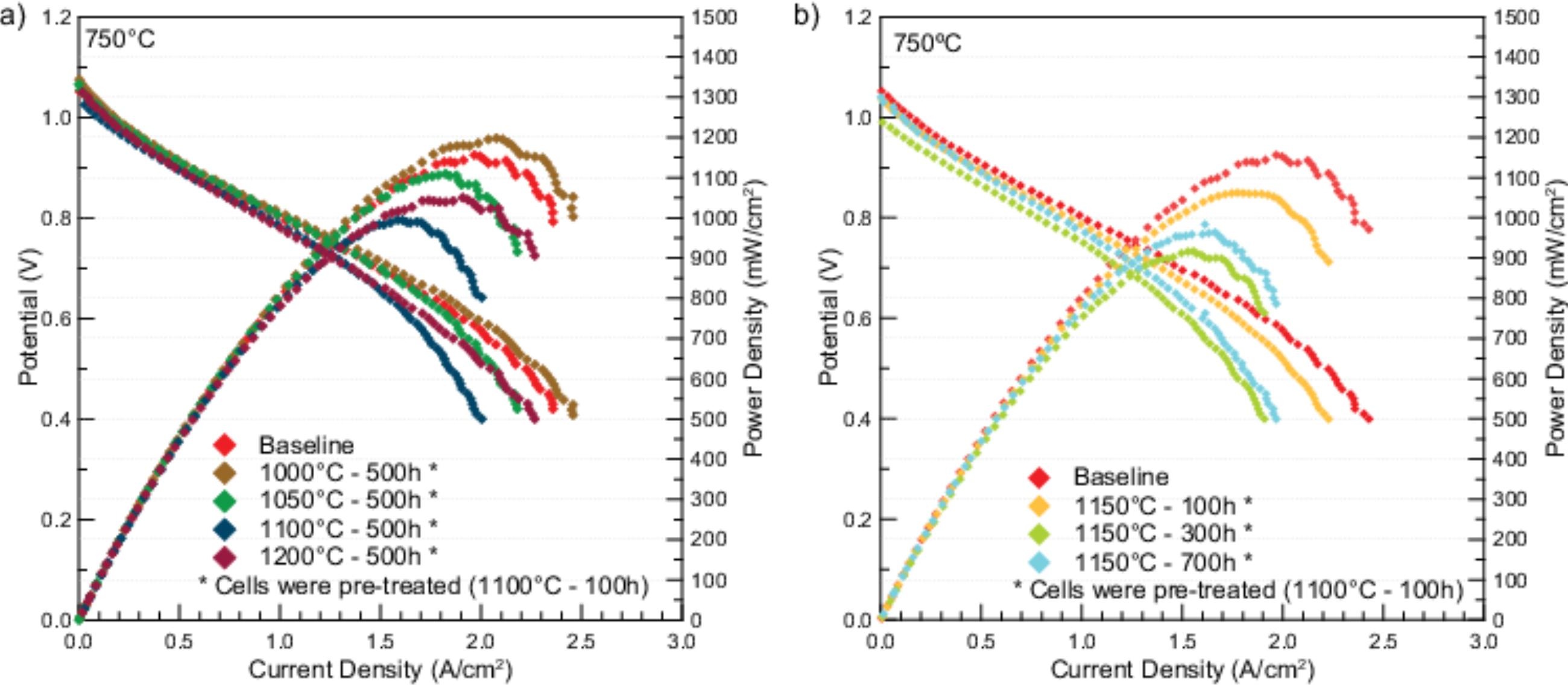


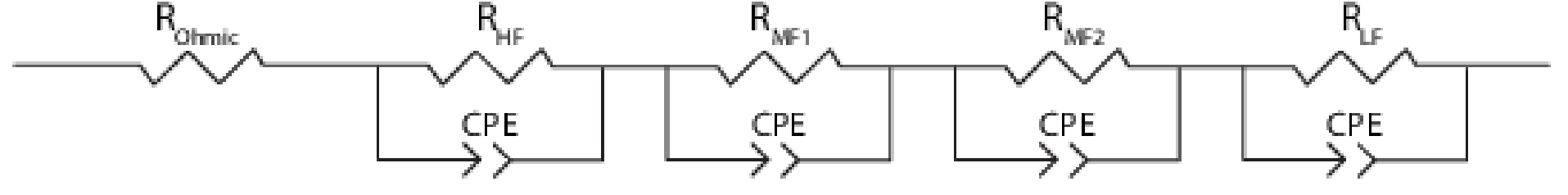

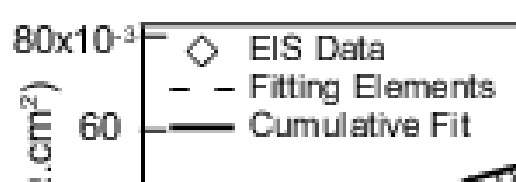

$\mathrm{C}_{40}$ $J_{x}$ $\therefore$

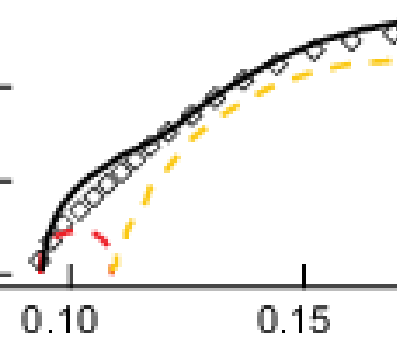

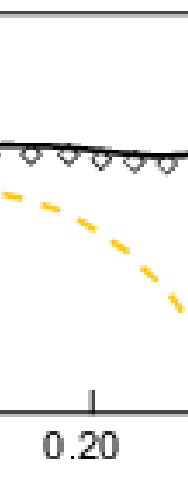
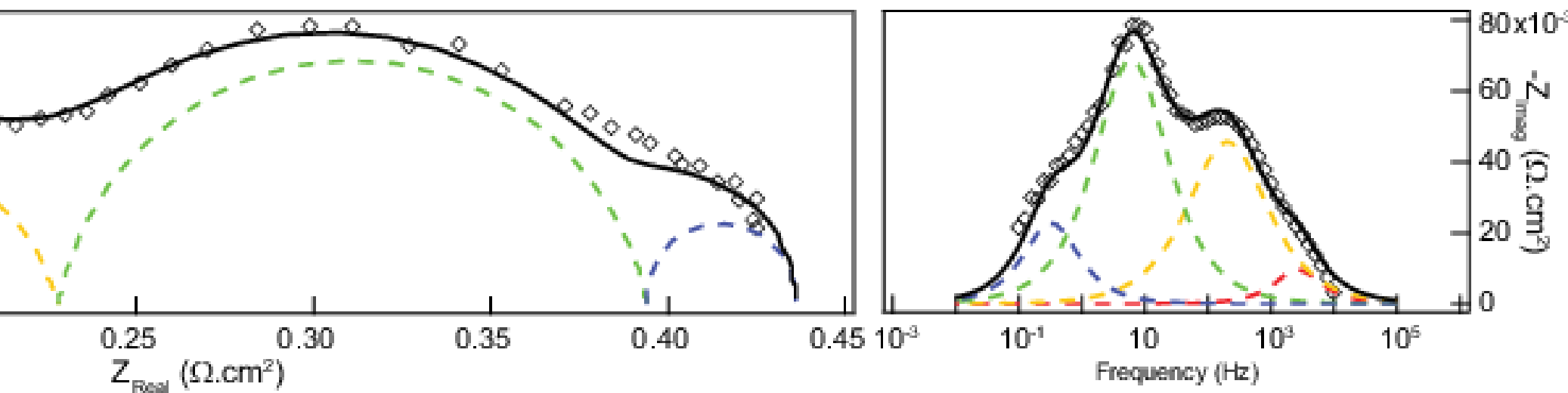


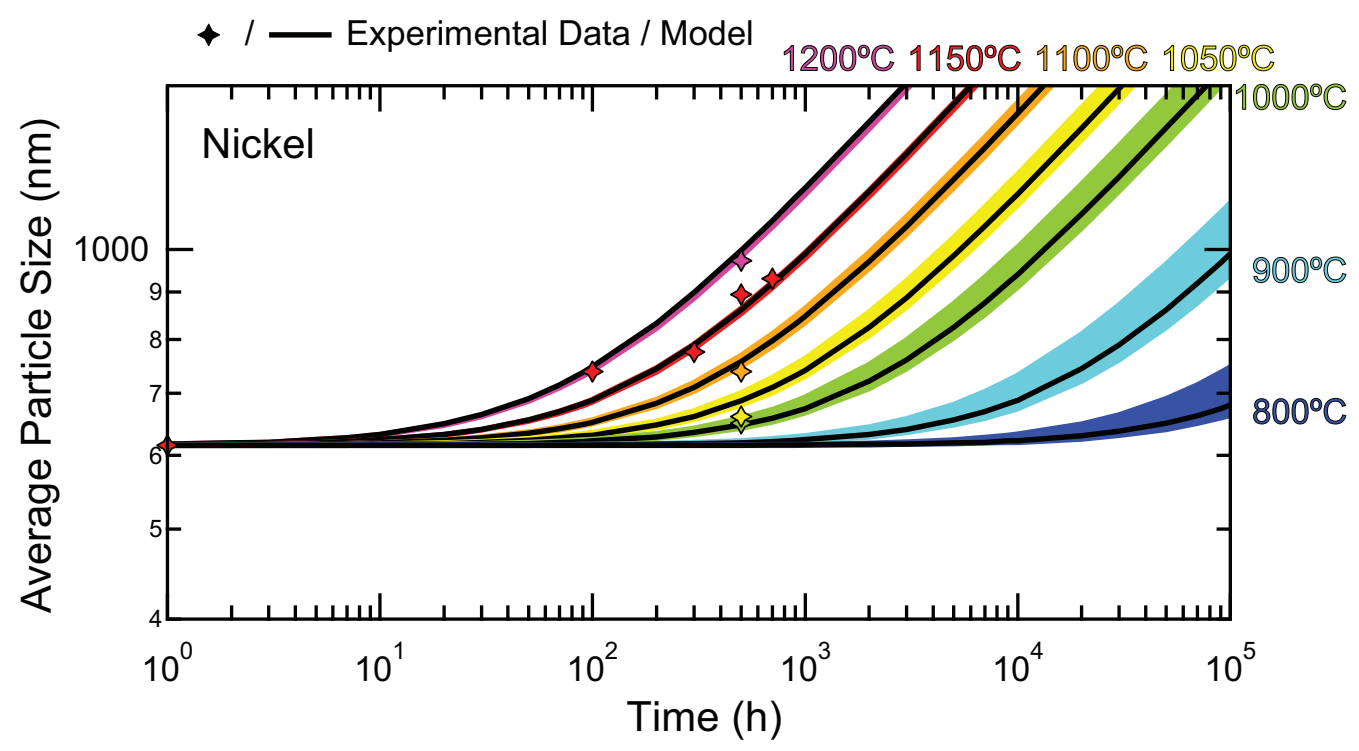

$1200^{\circ} \mathrm{C} 1150^{\circ} \mathrm{C} 1100^{\circ} \mathrm{C}$

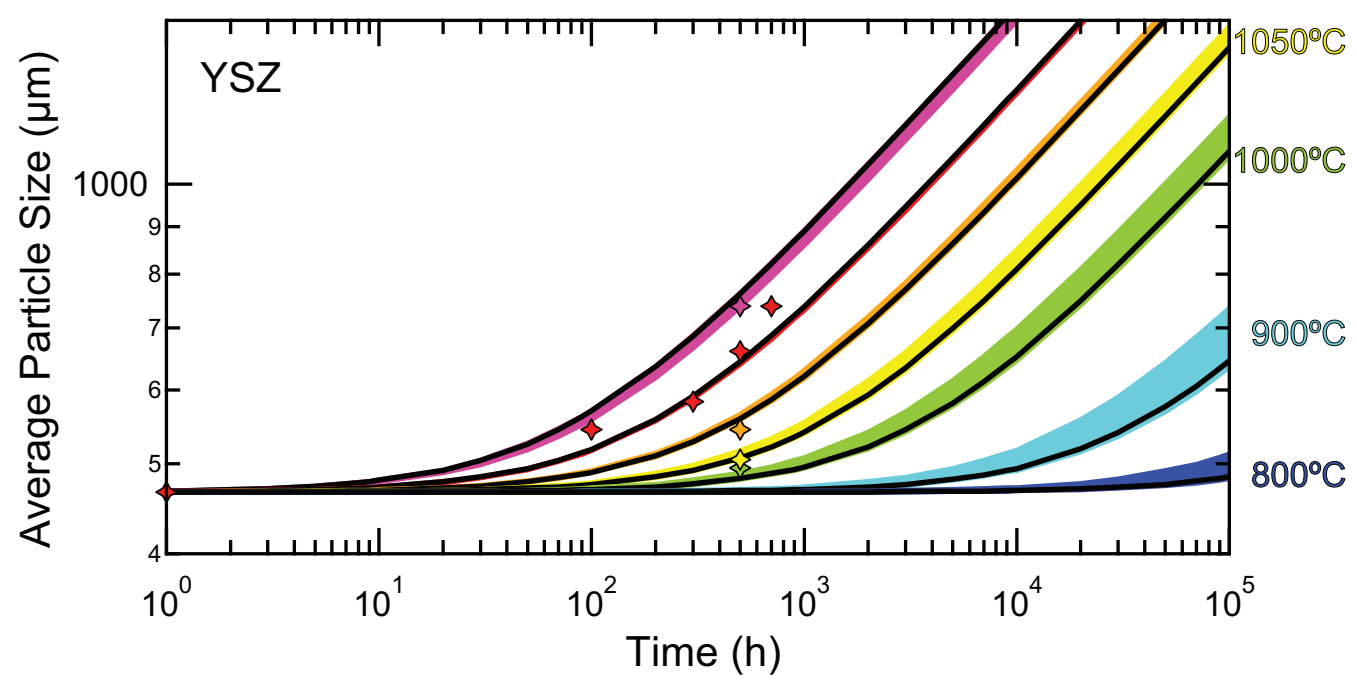


a)

$\downarrow /$ Experimental Data / Model

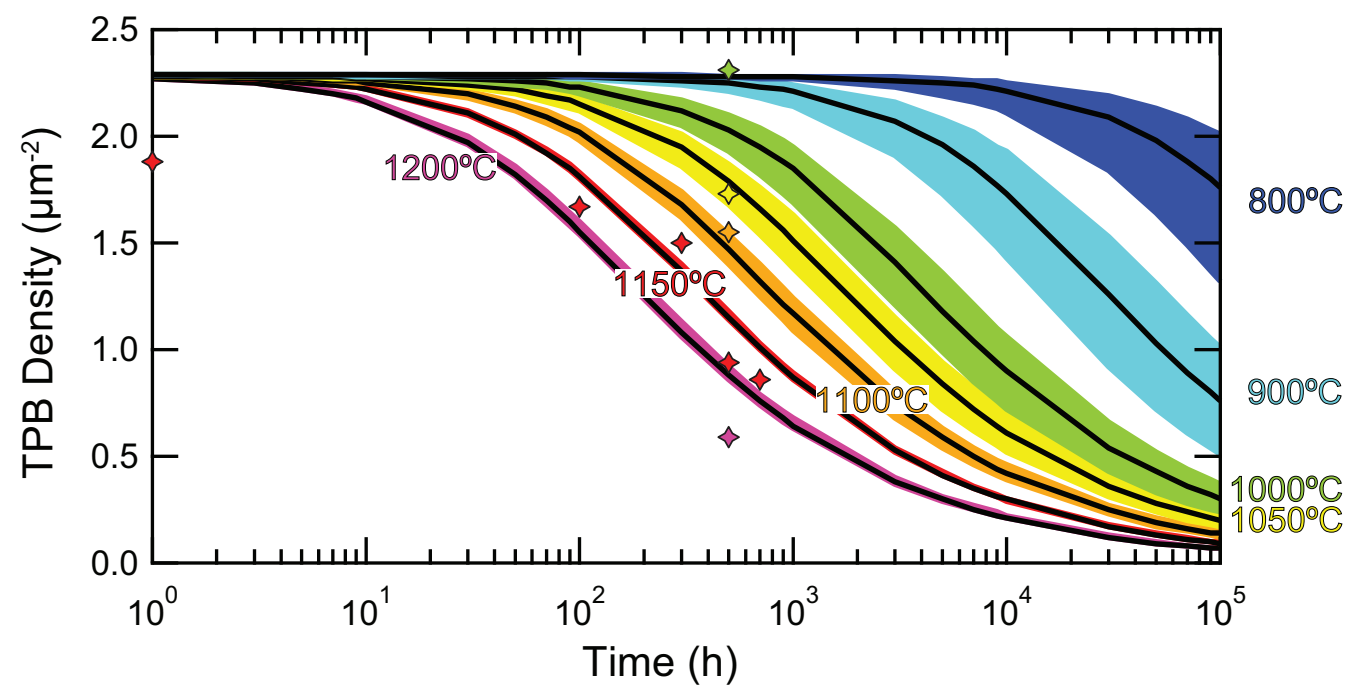

b)
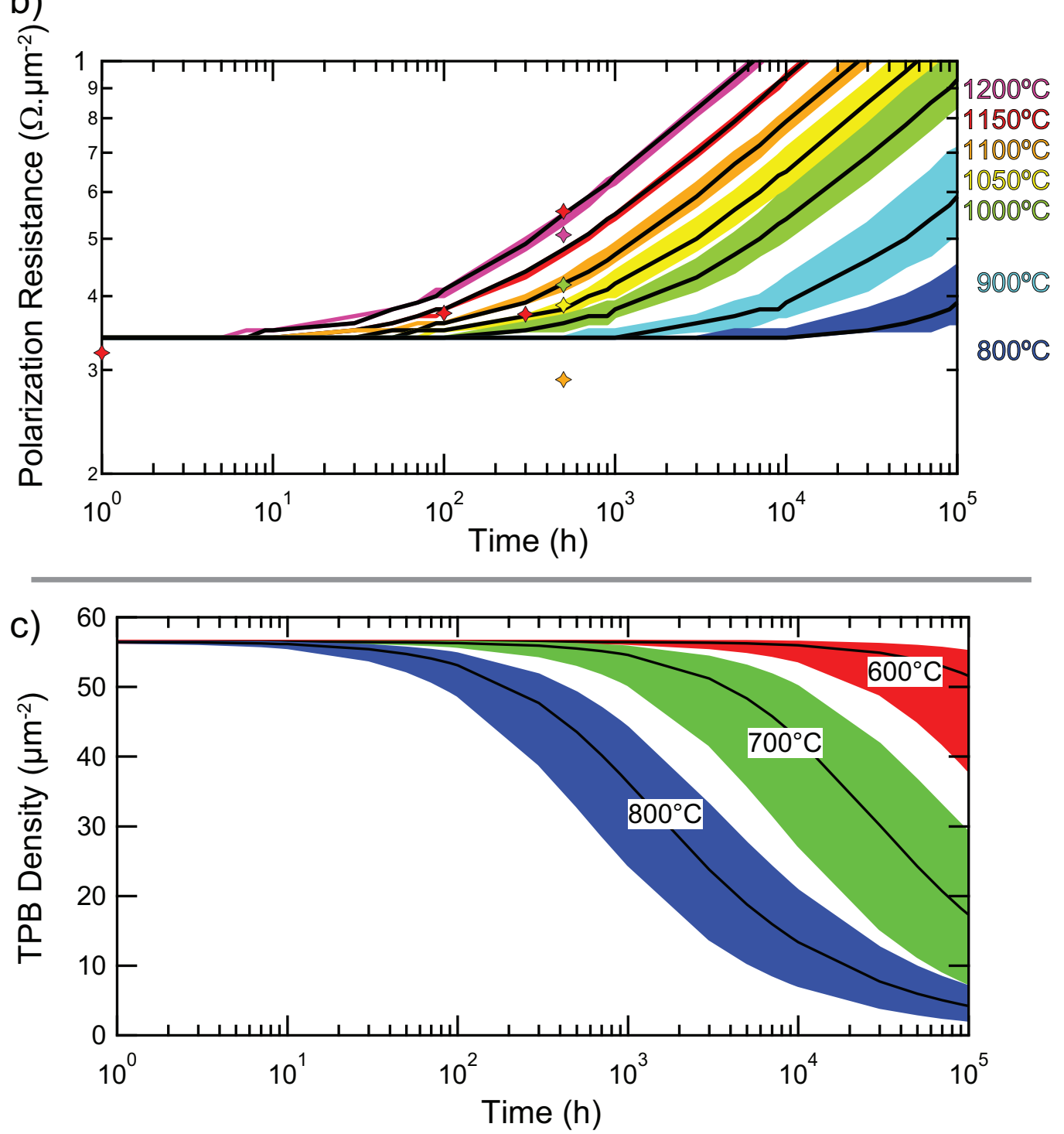